ISSN 2316-3054

\title{
ASPECTOS NORMATIVOS DA PROPAGANDA ELEITORAL NA INTERNET
}

\section{LEGAL ASPECTS OF THE ELECTORAL CAMPAIGN ON THE INTERNET}

\begin{abstract}
IRINEU FRANCISCO BARRETO JUNIOR
Doutor em Ciências Sociais pela Pontifícia Universidade Católica de São Paulo (2004). Docente do Programa de Mestrado em Direito da Sociedade da Informação da FMU e Coordenador Adjunto do Curso de Direito das Faculdades Metropolitanas Unidas FMU. Analista de Projetos Pleno da Fundação Sistema Estadual de Análise de Dados Seade. Docente do Programa de Mestrado em Ciências Sociais da Universidade de Vila Velha (UVV-ES). Professor Convidado da Escola Judicial do Trabalho da Segunda Região EJUD 02.
\end{abstract}

\begin{abstract}
MARCEL MACHADO MUSCAT
Advogado Eleitoral e Professor Universitário. Mestre em Direito da Sociedade da Informação pelas Faculdades Metropolitanas Unidas - FMU - SP.
\end{abstract}

\section{RESUMO}

Este artigo trata da aplicação das novas tecnologias informáticas, originárias da Sociedade da Informação, e sua relação com a Legislação Eleitoral Brasileira, particularmente no que concerte à utilização da Internet e das Redes Sociais como instrumento para propaganda eleitoral. As novas tecnologias são utilizadas para campanhas e propagandas eleitorais, o que muitas vezes ultrapassa a tênue linha entre o que admite a legislação brasileira e aquilo que é considerado uma infração eleitoral. Desta forma, a utilização de ferramentas tecnológicas e a hospedagem de propaganda eleitoral em sítios eletrônicos constitui-se uma realidade patente, porém, muitas vezes, no limiar das restrições normativas. A pesquisa pautou-se em análise hermenêutica da regulamentação eleitoral brasileira e na revisão doutrinária. 0 tema provoca uma série de abordagens, frente à característica irregular da propaganda que por fim culminou no advento da Lei 12.034/2009. Conclui-se que a normatividade brasileira é insuficiente para dirimir os conflitos que advém do uso da Internet nos sufrágios brasileiros. A dogmática não consegue acompanhar o célere ritmo das inovações tecnológicas, mas principalmente de uma sociedade cada vez mais conectada, que faz surgir fenômenos como o ativismo político virtual e a militância política na Internet.

Palavras-chave: Sociedade da Informação. Direito Eleitoral. Propaganda Eleitoral. Internet. Eleições.

\begin{abstract}
This article deals with the application of new information technologies, originating in the Information Society, and its relationship with the Brazilian electoral legislation. The new tools are also used for election campaigns and advertisements, which often exceeds the fine line between what Brazilian law allows and what is considered an election offense. Thus, the use of technological tools and hosting canvass in their websites is becoming a reality patent, however, often at the threshold of regulatory restrictions. The research was based on a hermeneutic analysis of the Brazilian electoral legislation and the doctrinal review. The issue caused a number of approaches, given the irregular character of the propaganda that eventually culminated in the enactment of Law 12.034/2009. It is concluded that the Brazilian normativity is insufficient to resolve the conflicts that comes from the use of the Internet in Brazil votes. Dogmatics can not follow the rapid pace of technological innovation, but mainly of a society increasingly connected, which gives rise to phenomena such as virtual political activism and political activism on the Internet.
\end{abstract}

Keywords: Information Society. Election Law. Election Campaign. Internet. Elections

REDESG / Revista Direitos Emergentes na Sociedade Global - www.ufsm.br/redesg v. 1, n. 2, jul.dez/2012

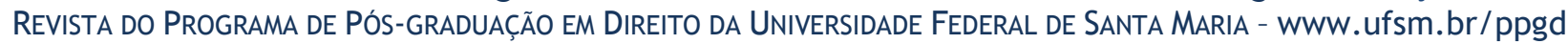




\section{SUMÁRIO}

SUMÁRIO: INTRODUÇÃO; 1. A CONSTITUIÇÃO FEDERAL; 2. A REGULAMENTAÇÃO DA PROPAGANDA ELEITORAL; 3. INTERNET E PROPAGANDA ELEITORAL; 3.1. Lei № 12.034/2009; 3.2. Resolução No 23.191/09 do Tribunal Superior Eleitoral; CONCLUSÃO; REFERÊNCIAS.

\section{INTRODUÇÃO}

É manifesto que o advento das novas tecnologias, fenômeno denominado de Sociedade da Informação é um grande marco histórico da sociedade pós-contemporânea, haja vista as significativas mudanças que vem realizando no cotidiano das pessoas e em sua interação com o mundo. Entretanto, a Sociedade da Informação possui uma luz que poderá trazer uma grande modificação na cultura eleitoral.

0 advento da Lei $n^{\circ} 12.034$ de 2009, trouxe importante progresso na utilização da rede mundial de computadores na disputa eleitoral a partir de 2010. Ademais, os artigos trazidos pela Lei $n^{\circ} 12.034$ de 2009, são nitidamente insuficientes, muitas vezes por falta de tipificação de algumas condutas, outras por pouco conteúdo. A partir dessa análise, poderemos traçar uma linha demarcatória da possibilidade de ascensão aos cargos Públicos eletivos por cidadãos comuns, interessados e com boas plataformas.

A Sociedade da Informação trouxe consigo a evolução das práticas eleitorais, ainda não muito bem delineadas pelo direito eleitoral brasileiro, mas marcadas por uma peculiaridade: diminuir a distância entre o candidato e o eleitor, diminuir os custos de campanha e democratizar ainda mais o processo eleitoral. Ademais, o trabalho desponta para a necessidade de ampliar a doutrina sobre direito eleitoral e dedicar uma reflexão mais profunda sobre o uso da Internet nas campanhas eleitorais, sobretudo com o intuito de aumentar as condições dos candidatos já ocupantes de cargos eletivos e aqueles que almejam tal mandato popular.

Este artigo trata da aplicação das novas tecnologias informáticas, originárias da Sociedade da Informação, e sua relação com a Legislação Eleitoral Brasileira, particularmente no que concerte à utilização da Internet e das Redes Sociais como instrumento para propaganda eleitoral. Discute se que a utilização de ferramentas tecnológicas e a hospedagem de propaganda eleitoral em sítios eletrônicos constitui-se uma realidade patente, porém, muitas vezes, no limiar das restrições normativas. A pesquisa pautou-se em análise hermenêutica da regulamentação eleitoral brasileira, na revisão doutrinária e na compilação de casos práticos e julgados. Portanto, esse trabalho é de fundamental importância no contexto global de democracia e está inserido num projeto de amadurecimento político eleitoral fundamental para 
termos mais segurança jurídica e trilharmos o espírito maior do termo: Estado Democrático e Social de Direito.

\section{A CONSTITUIÇÃO FEDERAL}

O texto constitucional traz em seu bojo as diretrizes de organização da República Federativa do Brasil, dentre eles, a organização do sistema eleitoral brasileiro. Haja vista que todo o poder emana do povo, que o exerce por meio de seus representantes, e que tal representação é consagrada por meio do voto, sendo este direto, secreto e periódico, como verdadeira consagração do Estado Democrático de Direito, a Constituição Federal traçou as diretrizes para a garantia do sufrágio.

Deve-se, preliminarmente, mencionar e analisar os princípios e regras constitucionais que embasam a propaganda eleitoral, e após, verificar como as novas tecnologias afetam o sufrágio. Em outras palavras, após a análise da regulamentação da propaganda eleitoral prescrita no Texto Maior, deve-se verificar a incidência da Internet nas eleições. A Constituição institui e legitima o poder político, conforme os ensinamentos de Canotilho:

A Constituição em sentido moderno pretendeu, como vimos, radicar duas ideias básicas: 1) ordenar, fundar e limitar o poder político; 2) reconhecer e garantir os direitos e liberdades da individuo. Os temas centrais do constitucionalismo são, pois, a fundação e legitimação do poder político e a constitucionalização das liberdades ${ }^{1}$.

Nesse diapasão, o preâmbulo da Constituição Federal, que possui força interpretativa, enuncia princípios tais como: a liberdade, a igualdade, e a justiça como valores supremos de uma sociedade fraterna, pluralista e sem preconceitos, baseada na harmonia social e na solução pacífica das controvérsias. 0 artigo $1^{\circ}$ da Carta Magna descreve que a República Federativa do Brasil constitui-se em Estado Democrático de Direito, tendo como fundamentos, dentre outros, a cidadania, a dignidade da pessoa humana e o pluralismo político. Tais preceitos deflagram na existência de eleições livres e amplas, possibilitando a escolha livre e secreta de representantes que se vinculam as ideias trazidas e debatidas nas eleições como suas premissas de trabalho representativo.

A Constituição Federal trouxe parâmetros elementares para o desenvolvimento legal da atividade partidária, sobretudo no que tange a forma e os meios pelos quais os candidatos

\footnotetext{
${ }^{1}$ CANOTILHO, J.J. Gomes. Direito constitucional e teoria da Constituição. $2^{\text {a }}$ ed. Coimbra: Almedina, 1998, p.282.
} 
devem se ancorar na realização das campanhas eleitorais e da mesma forma para qual órgão jurisdicional necessita reportar-se. Esses elementos estão detalhados no corpo dos artigos. 14 ao 17, razão pela qual, remetemo-nos ao exame dos preceitos constitucionais para logo após essa reflexão, emaranharmos no campo específico da legislação eleitoral.

0 texto do artigo 14 da Lição Fundamental determina como se dá e quais os critérios basilares do sufrágio universal, consagrando o exercício da democracia, feito de forma direta e secreta, sua formas de estágio, os critérios para exercê-los e suas limitações, idade para concorrer aos diversos cargos públicos, sobretudo dispõe sobre as reeleições.

Nesse diapasão, o artigo 15 disciplina a cassação dos direito políticos e texto do art. 16 regulamenta o prazo necessário para que uma alteração, em matéria eleitoral, tenha validade, ou seja, um ano antes do pleito. Já o artigo 17 nos traz os elementos normativos para constituição de partidos políticos suas formas, abrangência, a quem respondem e seus papeis na sociedade. Delimitando assim que tem abrangência nacional, proibição de recebimento de recursos financeiros de entidade ou governo estrangeiros ou de subordinação a estes, prestação de contas à Justiça Eleitoral, funcionamento parlamentar de acordo com a lei.

Deste modo, conforme o parágrafo $1^{\circ}$ e seguintes do art. 17 , os partidos políticos ainda devem definir sua estrutura interna, organização e funcionamento e para adotar os critérios de escolha e o regime de suas coligações eleitorais, sem obrigatoriedade de vinculação entre as candidaturas em âmbito nacional, estadual, distrital ou municipal, devendo seus estatutos estabelecer normas de disciplina e fidelidade partidária.

Destarte, esses elementos são fundamentais para o entendimento do processo eleitoral com um todo, de forma que esses preceitos estão notadamente instituídos no texto da Legislação Eleitoral, Lei nº 9.504/97.

Assim, os elementos trazidos acima, são premissas que norteiam as eleições e seus debates, fornecendo elementos que são respeitados no Código Eleitoral, legislação Eleitoral e nas Resoluções do TSE. Portanto, cumpre ressaltar a importância do estudo constitucional na persecução desse trabalho, trazendo seus preceitos com intuito, de encontrarmos um processo eleitoral sadio, honesto e garantidor das liberdades constitucionais.

Corroborando com tal entendimento, vejamos como pensa o professor Marcos Vinicius Furtado Coêlho:

Sendo a Constituição Federal a norma fundamental do Estado, instituidora de ente estatal e legitimadora de todo o ordenamento, a aplicação das demais normas que disciplinam o tema devem guardar perfeita adequação com o 
propósito desta que é norma de maior hierarquia e eficácia do sistema jurídico pátrio ${ }^{2}$.

Passada a necessária introdução ao tema, devem ser destacados três grupos de princípios basilares da propaganda eleitoral, sendo todos oriundos da Constituição Federal. A expressão de pensamento de forma livre, a comunicação social e a proibição de censura, são elementos basilares que norteiam a propaganda eleitoral. São elementos inerentes às eleições, pois os candidatos a representantes do povo devem se expressar livremente e apresentar suas propostas de governo, sem a interferência de terceiros ou de interesses políticos que possam prejudicar a lisura das eleições. Em outras palavras, a propaganda eleitoral deve ser apresentada de forma livre, sem censura prévia. Os candidatos que pretendem ser eleitos devem demonstrar, durante sua campanha política, seus projetos e apontar, demais disso, os motivos que teoricamente os fariam merecedores de eleição pela população.

Livre manifestação de pensamento, comunicação social e vedação de censura são princípios insculpidos no artigo $5^{\circ}$ da Constituição Federal, que traz um extenso rol exemplificativo de direitos e garantias fundamentais. Faz-se necessário, portanto, a transcrição dos dispositivos que servem de base à propaganda eleitoral, ressaltando-se que tais princípios podem ser invocados em diversas situações em que a liberdade de expressão esteja ameaçada:

\footnotetext{
Art. $5^{\circ}$. omissis

IV - é livre a manifestação do pensamento, sendo vedado o anonimato;

$\checkmark$ - é assegurado o direito de resposta, proporcional ao agravo, além da indenização por dano material, moral ou à imagem;

IX - é livre a expressão da atividade intelectual, artística, científica e de comunicação, independentemente de censura ou licença;

XIV - é assegurado a todos o acesso à informação e resguardado o sigilo da fonte, quando necessário ao exercício profissional;
}

Cabível ainda, no tocante à liberdade de expressão e informação, fundamentais no âmbito de campanhas eleitorais (haja vista que a propaganda eleitoral deve servir não apenas para promover o candidato, mas deve informar e orientar o eleitor para que faça a escolha certa ao eleger seus representantes), mencionar o teor do artigo 220 do texto constitucional, que prescreve, in verbis:

Art. 220. A manifestação do pensamento, a criação, a expressão e a informação, sob qualquer forma, processo ou veículo não sofrerão qualquer restrição, observado o disposto nesta Constituição.

${ }^{2}$ COÊLHO, Marcos Vinicius Furtado. Direito Eleitoral e Processo Eleitoral-Direito penal eleitoral e direito político. $2^{\text {a }}$ ed., Rio de Janeiro: Renovar, 2010, p.109. 
$\S 1^{\circ}$ - Nenhuma lei conterá dispositivo que possa constituir embaraço à plena liberdade de informação jornalística em qualquer veículo de comunicação social, observado o disposto no art. $5^{\circ}$, IV, V, X, XIII e XIV.

$\S 2^{\circ}$ - É vedada toda e qualquer censura de natureza política, ideológica e artística.

[...] omissis

Nota-se, após a transcrição dos dispositivos constitucionais, que a atuação da Justiça Eleitoral, no tocante a eventuais abusos durante a veiculação de propagandas deve ser de forma repressiva, ou seja, após a veiculação da propaganda, sob pena de configuração de censura. A atuação da Justiça Eleitoral deve ser mediante provocação (incidência do princípio da inércia da jurisdição), sempre posterior à veiculação da propaganda eleitoral que não atende às diretrizes do Código Eleitoral, ou fere, frontalmente, princípios constitucionais basilares (por exemplo, a veiculação de ofensas ou expressões de baixo calão em face de candidatos adversários).

Thales Tácito Pontes Luz de Pádua Cerqueira explica que a atuação repressiva da Justiça Eleitoral se deve porque “[...] a destinação da informação é o eleitor, razão pela qual não se admite medida cautelar preparatória, mas sim incidental, a partir da intervenção constitucional da Justiça Eleitoral.3“.

Realizadas as considerações pertinentes no tocante ao primeiro grupo de princípios, que se traduzem em ditames constitucionais basilares no que se refere à liberdade de expressão, deve-se analisar, por conseguinte, a isonomia, tão perseguida até os dias atuais pelas nações democráticas. 0 princípio da isonomia foi objeto do Capítulo I, que teve por tema a análise dos princípios constitucionais que incidem sobre o direito eleitoral, bem como os princípios específicos que norteiam o Direito Eleitoral. Desta forma, será realizado um breve apanhado acerca do princípio em epígrafe, enfatizando-se o viés eleitoral.

Preliminarmente, insta destacar a lição de Thales Tácito Pontes Luz de Pádua Cerqueira, no tocante à quebra da isonomia no Direito Eleitoral. Para ele, a quebra da isonomia deve atender a três requisitos:

$1^{\circ}$. 0 elemento tido como desigualador (critério diferencial) não pode singularizar o presente e, em modo absoluto, um único sujeito. 0 critério deve, sim, singularizar traço que reside na pessoa numa situação inerente a ela mesma, numa visão de universalidade ou ocorrência contínua de norma ao longo do tempo (o critério usado para diferenciação deve ensejar muitas diferenciações em abstrato, imprevisíveis ao longo do tempo);

$2^{\circ}$. O elemento tido como desigualador (critério diferencial) deve se ater à correlação módico-abstrata entre fator redigido em critério de discriminação e a disparidade estabelecida no tratamento jurídico diversificado, ou seja, o critério

\footnotetext{
${ }^{3}$ CERQUEIRA, Thales Tácito Pontes Luz de Pádua. Direito eleitoral brasileiro: doutrina, jurisprudência e legislação. 2 ed. Belo Horizonte, MG: Del Rey Editora, 2002, p.498. 
para diferenciar o particular em face do geral e permitir ao mesmo tempo um traço a mais ou a menor de isonomia diverso do geral há de ser admitido no próprio sistema constitucional.

$3^{\circ}$. O elemento tido como fator desigualador (critério diferencial) deve ser ater à consonância desta correlação lógica dos critérios com os interesses absorvidos no sistema constitucional (no caso, a informação ao eleitor, que deve ficar educado, esclarecido e informado de sua participação e importância na escolha de candidatos e partidos no processo eleitoral). ${ }^{4}$

Pode-se afirmar que a isonomia no tocante à propaganda eleitoral é tida pela igualdade de oportunidade entre partidos, haja vista que a veiculação de propaganda nos meios de comunicação é gratuita, no entanto, o acesso é compartilhado de forma proporcional à representação na bancada legislativa federal. Neste sentido, prescreve o artigo $17, \$ 3^{\circ}$ da Constituição Federal "Art. 17. Omissis. $\$ 3^{\circ}$ - Os partidos políticos têm direito a recursos do fundo partidário e acesso gratuito ao rádio e à televisão, na forma da lei". Deve-se ressaltar que a regra constitucional prescrita acima é regulamentada pela Lei $n^{\circ} 9.504 / 97$, em seu artigo 47, que dispõe, in verbis:

Art. 47. As emissoras de rádio e de televisão e os canais de televisão por assinatura mencionados no art. 57 reservarão, nos quarenta e cinco dias anteriores à antevéspera das eleições, horário destinado à divulgação, em rede, da propaganda eleitoral gratuita, na forma estabelecida neste artigo.

[...] omissis

$\S 2^{\circ}$ Os horários reservados à propaganda de cada eleição, nos termos do parágrafo anterior, serão distribuídos entre todos os partidos e coligações que tenham candidato e representação na Câmara dos Deputados, observados os seguintes critérios:

I - um terço, igualitariamente;

II - dois terços, proporcionalmente ao número de representantes na Câmara dos Deputados, considerado, no caso de coligação, o resultado da soma do número de representantes de todos os partidos que a integram.

$\S 3^{0}$ Para efeito do disposto neste artigo, a representação de cada partido na Câmara dos Deputados é a resultante da eleição.

$\S 4^{\circ} \mathrm{O}$ número de representantes de partido que tenha resultado de fusão ou a que se tenha incorporado outro corresponderá à soma dos representantes que os partidos de origem possuíam na data mencionada no parágrafo anterior.

$\S 5^{\circ}$ Se o candidato a Presidente ou a Governador deixar de concorrer, em qualquer etapa do pleito, e não havendo a substituição prevista no art. 13 desta Lei, far-se-á nova distribuição do tempo entre os candidatos remanescentes.

$\S 6^{\circ}$ Aos partidos e coligações que, após a aplicação dos critérios de distribuição referidos no caput, obtiverem direito a parcela do horário eleitoral inferior a trinta segundos, será assegurado o direito de acumulá-lo para uso em tempo equivalente.

${ }^{4}$ Ibidem, , p.498-499. 
Tem-se, pela leitura do dispositivo, que o acesso aos meios de comunicação para o exercício da propaganda eleitoral deve ser compartilhado, observando-se as regras contidas no artigo 47, qual seja, o acesso compartilhado, proporcional à bancada legislativa federal, mas assegurado um mínimo de igualdade, que é de um terço. De fato, a igualdade, em se tratando de direito eleitoral, deve seguir os ditames constitucionais em sua plenitude, remontando a máxima aristotélica, qual seja, tratar igualmente os iguais e desigualmente os desiguais, na medida de suas desigualdades. Por derradeiro, deve-se mencionar que o princípio da igualdade, no que tange às oportunidades entre os candidatos, deve observar o regime de inelegibilidades, para garantir a inexistência de vícios no tocante às eleições. 0 último conjunto de princípios constitucionais a serem tratados neste tópico referem-se às eleições propriamente ditas, a garantia de liberdade do eleitor em sua escolha para a votação, bem como a garantia do próprio sufrágio, corolário da democracia.

De fato, a Constituição Federal, nos artigos 14 a 16, disciplina os direitos políticos. Importante destacar alguns trechos do artigo 14, in verbis:

Art. 14. A soberania popular será exercida pelo sufrágio universal e pelo voto direto e secreto, com valor igual para todos, e, nos termos da lei, mediante: (grifo nosso).

\section{[...] omissis}

$\S 1^{\circ}$ - 0 alistamento eleitoral e o voto são:

I - obrigatórios para os maiores de dezoito anos;

II - facultativos para:

a) os analfabetos;

b) os maiores de setenta anos;

c) os maiores de dezesseis e menores de dezoito anos.

[...]

$\S 4^{\circ}$ - São inelegíveis os inalistáveis e os analfabetos.

$\S 5^{\circ} \mathrm{O}$ Presidente da República, os Governadores de Estado e do Distrito Federal, os Prefeitos e quem os houver sucedido, ou substituído no curso dos mandatos poderão ser reeleitos para um único período subsequente.

[...] omissis

$\S 9^{\circ}$ Lei complementar estabelecerá outros casos de inelegibilidade e os prazos de sua cessação, a fim de proteger a probidade administrativa, a moralidade para exercício de mandato considerada vida pregressa do candidato, e a normalidade e legitimidade das eleições contra a influência do poder econômico ou o abuso do exercício de função, cargo ou emprego na administração direta ou indireta.

$[\ldots]$ 
Do caput do artigo 14, observa-se que a Constituição Federal consagrou, por meio do sufrágio, a forma de escolha de seus representantes. Importante assinalar, preliminarmente, que “todo brasileiro pode ascender à condição de cidadão ativo, isto é, de eleitor.5”

Os direitos políticos em face do direito positivo pátrio são situações subjetivas expressas ou implicitamente contidas em preceitos e princípios constitucionais, reconhecendo aos brasileiros o poder de participação na condução dos negócios públicos: (a) votando, (b) sendo votado, inclusive investindo-se em cargos públicos e (c) fiscalizando os atos do poder público, visando ao controle da legalidade e da moralidade administrativa. ${ }^{6}$

No mais, insta destacar o conceito de sufrágio como “ um direito público subjetivo de natureza política, que tem o cidadão de eleger, ser eleito e participar da organização e da atividade do poder estatal.7" Ressalte-se, neste contexto, que o sufrágio compreende o direito de voto, mas com ele não se confunde:

[...] as palavras sufrágio e voto são empregadas comumente como sinônimo. A Constituição Federal, no entanto, dá-lhes sentidos diferentes, especialmente, no seu artigo 14, por onde se vê que o sufrágio é universal e o voto é direto e secreto e tem valor igual. A palavra voto é empregada em outros dispositivos, exprimindo a vontade num processo decisório. Escrutínio é outro termo com que se confundem as palavras sufrágio e voto. É que os três se inserem no processo de participação do povo no governo, expressando: um, o direito (sufrágio), outro, o seu exercício (o voto), e o outro, o modo de exercício (escrutínio). ${ }^{8}$

Com vista à garantia do sufrágio, que a Constituição elencou um capítulo especificamente destinado aos direitos políticos dos cidadãos, sejam eles eleitores ou candidatos. Há limites impostos pelo texto constitucional no tocante aos abusos de poder nas eleições. Conforme ressalta Thales Tácito Pontes Luz de Pádua Cerqueira,

Pensando nas eleições livres, a lei infraconstitucional previu normas de limites e de controle de gastos eleitorais; a sanção de cassação de registro ou do diploma passou a ter expressa previsão na Lei $n^{\circ} 9504 / 97$, modificada que foi pela Lei $n^{\circ}$ 9.840/99, sugerida pela CNBB (Conferência Nacional dos Bispos do Brasil); estabeleceu condições para a propaganda paga na imprensa (espaço máximo da propaganda por edição), para que o poder econômico de uns não resulte em dificuldade ou impossibilidade de acesso a outros etc ${ }^{9}$.

${ }^{5}$ FERREIRA FILHO, Manoel Gonçalves. Curso de Direito Constitucional. 35 ed. São Paulo: Saraiva, 2009, p.116.

6 JARDIM, Torquato. Direito eleitoral positivo. Brasília, DF: Livraria e Editora Brasília Jurídica, 1996, p.52.

${ }^{7}$ MORAES, Alexandre de. Direito Constitucional. 25 ed. São Paulo: Atlas, 2010, p.230.

${ }^{8}$ SILVA, José Afonso da. Curso de Direito Constitucional Positivo. 33 ed. São Paulo: Malheiros Editores, 2010, p. 349.

${ }^{9}$ CERQUEIRA, Thales Tácito Pontes Luz de Pádua. Direito eleitoral brasileiro: doutrina, jurisprudência e legislação. 2 ed. Belo Horizonte, MG: Del Rey Editora, 2002, p.501.

REDESG / Revista Direitos Emergentes na Sociedade Global - www.ufsm.br/redesg v. 1, n. 2, jul.dez/2012 ReVISTA do Programa de Pós-graduação em DiREITO da Universidade Federal de SANTA MARIA - www.ufsm.br/ppgd 
Em síntese, os três conjuntos de princípios constitucionais ora apresentados são verdadeiras diretrizes ao controle da propaganda eleitoral, no que tange à garantia de lisura no processo eleitoral. Os próximos tópicos se prestam a analisar propriamente a regulamentação da propaganda eleitoral, tanto por meio televisivo e radiofônico, quanto por meio da Internet.

\section{A REGULAMENTAÇÃO DA PROPAGANDA ELEITORAL}

Antes de adentrar no tema propriamente dito, vale destacar as disposições da Lei $\mathrm{n}^{\circ}$ 9504/97 no tocante à propaganda eleitoral, difundida nos meios de comunicação. Insta ressaltar, preliminarmente, que a Constituição Federal reservou as diretrizes da propaganda eleitoral, mas sua regulamentação foi realizada pela legislação infraconstitucional.

Forçoso transcrever uma definição de propaganda, trazida por Fávila Ribeiro: “a propaganda é um conjunto de técnicas empregas para sugestionar pessoas na tomada de decisão.10" De fato, a propaganda é utilizada para atingir consumidores, difundir ideias e principalmente, é um dos meios mais eficazes na conquista do eleitorado. Prossegue Fávila Ribeiro:

Despreza a propaganda a argumentação racional, prescindindo do esforço persuasivo para demonstração lógica da procedência de um tema. Procura, isto sim, desencadear, ostensiva e veladamente, estados emocionais que possam exercer influência sobre as pessoas. Por isso mesmo, com a propaganda não se coadunam a análise crítica de diferentes posições, desde que procura induzir por recursos que atuam diretamente no subconsciente individual. ${ }^{11}$

$\mathrm{Na}$ legislação pátria, a propaganda eleitoral, mais que um direito de expressão consagrado pela Constituição Federal, consubtancia-se num direito disciplinado no próprio Código Eleitoral (Lei $n^{\circ} 4.737 / 65$ )

A liberdade de propaganda mereceu compatível tratamento, como condição básica do processo eleitoral, garantindo a persistência de seguro esquema para funcionamento da competição democrática. As normas protetoras da liberdade aparecem em funcional implicação com os postulados de igualdade. Com a liberdade erguem-se as defesas dos eleitores, dos candidatos e dos partidos, impedindo os cerceamentos provindos das agências estatais. Por sua vez, com a igualdade, as defesas são mobilizadas para enfrentar as situações privilegiadas,

\footnotetext{
${ }^{10}$ RIBEIRO, Fávila. Direito Eleitoral. 5 ed. Rio de Janeiro:Forense, 1998, p.445.

${ }^{11}$ Ibidem, mesma página. 
as dominações sociais que possam de alguma maneira embaraçar e desnivelar o livre diálogo democrático. ${ }^{12}$

Vale destacar, em linhas gerais (haja vista que o tema será melhor delineado nos itens seguintes), que a liberdade de propaganda eleitoral está disciplinada no artigo 248 do Código Eleitoral (Lei $\left.n^{\circ} 4.737 / 65\right)$, que prescreve, in verbis: “At. 248. Ninguém poderá impedir a propaganda eleitoral, nem inutilizar, alterar ou perturbar os meios lícitos nela empregados." No mais, a inobservância ao dispositivo acima acarreta sanção de natureza penal, conforme prescreve o artigo 331 do mesmo diploma legal, in verbis:

Art. 331. Inutilizar, alterar ou perturbar meio de propaganda devidamente empregado:

Pena - detenção até seis meses ou pagamento de 90 a 120 dias-multa.

Art. 332. Impedir o exercício de propaganda:

Pena - detenção até seis meses e pagamento de 30 a 60 dias-multa.

Interessante destacar a lição de Joel J. Cândido, que elenca os princípios da propaganda eleitoral:

$1^{\circ}$. Princípio da Legalidade - o primeiro, ao qual se vinculam todos os demais, plenamente em vigor em nosso sistema eleitoral, e que consiste na afirmação de que a lei federal regula a propaganda, estando o ordenamento composto por regras cogentes, de ordem pública, indisponíveis e de incidência e acatamento erga omnes.

$2^{\circ}$. Princípio da liberdade - é o livre direito à propaganda, na forma que dispuser a lei.

$3^{\circ}$. Princípio da Responsabilidade - toda a propaganda é de responsabilidade dos partidos políticos e coligações, solidários com os candidatos e adeptos pelos abusos e excessos que cometerem.

$4^{\circ}$ Princípio Igualitário - todos, com igualdade de oportunidades, têm direito à propaganda, paga ou gratuita.

$5^{\circ}$. Princípio da Disponibilidade - decorrente do Princípio da Liberdade da Propaganda, significa que os partidos políticos, coligações, candidatos e adeptos podem dispor da propaganda lícita, garantida e estimulada pelo Estado, já que a lei pune com sanções penais a propaganda criminosa e pune a propaganda irregular com sanções administrativas - eleitorais, precipuamente.

$6^{\circ}$. Princípio do Controle Judicial da Propaganda - consiste na máxima segundo a qual a Justiça Eleitoral, exclusivamente, incumbe a aplicação das regras jurídicas sobre a propaganda e, inclusive, o exercício do seu Poder de Polícia ${ }^{13}$.

De fato, o legislador não se limitou a repetir a liberdade de expressão, genericamente prescrita na Constituição Federal e aprimorada por diploma específico. O legislador entendeu que a simples consagração não era suficiente para tutelar o direito à propaganda eleitoral, e

\footnotetext{
${ }^{12}$ Ibidem, p.462-464.

${ }^{13}$ CANDIDO, Joel. Direito Eleitoral Brasileiro. 13 ed: Edipro, 2008, p.154-155.
}

REDESG / Revista Direitos Emergentes na Sociedade Global - www.ufsm.br/redesg v. 1, n. 2, jul.dez/2012 ReVISTA do Programa de Pós-graduação em DireIto da UnIVERSIDAde Federal de SANTA MARIA - www.ufsm.br/ppgd 
desta forma, disciplinou o desrespeito ao exercício desse direito como crime, conforme observado pela leitura dos artigos 331 e 332 do Código Eleitoral Brasileiro.

Outra informação de destaque no tocante às propagandas de cunho eleitoral é a denominação conferida pela lei. Mencionou-se no presente trabalho, por diversas ocasiões, a expressão "propaganda eleitoral”, por ser lato sensu, a mais utilizada. No entanto, a distinção a seguir esclarecida não é criação da doutrina, mas da própria legislação. Desta forma, tem-se genericamente a propaganda partidária. Esta possui três espécies, a saber: propaganda eleitoral (artigo 36, caput, da Lei $n^{\circ}$ 9504/97), propaganda intrapartidária (artigo 36, $\S 1^{\circ}$ da Lei $n^{\circ}$ 9.504/97) e propaganda partidária (artigo 36, § $2^{\circ}$ da Lei $n^{\circ}$ 9.504/97). Em primeiro lugar, apresentamos a definição de propaganda eleitoral, trazida por Omar Chamon:

[...] está permitida apenas a partir de 6 de julho do ano das eleições e durará até quarenta e oito horas antes do primeiro turno e, se houver, do segundo turno das eleições. Está igualmente proibida qualquer propaganda nas vinte e quatro horas posteriores às eleições.

A propaganda será apresentada, obrigatoriamente, em português e não poderá criar, artificialmente, na opinião pública, estados mentais (mensagens subliminares), emocionais ou passionais. Deverá mencionar sempre o partido responsável. ${ }^{14}$

Conforme se depreende da explicação do referido autor, a propaganda eleitoral é a espécie de propaganda que possui por finalidade a divulgação de ideias e dos programas com a proposta de governo dos candidatos. Em segundo lugar, apresentamos a definição de propaganda intrapartidária, também trazida pela lição de Omar Chamon:

é permitida quinze dias antes da convenção partidária e visa atingir, exclusivamente, os convencionais, isto é, aqueles que escolherão os candidatos que disputarão a eleição por determinado partido político. Não admite o uso de rádio, televisão ou outdoor. Todavia, é possível a colocação de cartazes próximos ao diretório partidário. Toda propaganda deverá ser retirada, imediatamente, após a convenção. A sanção na hipótese de descumprimento dessa norma é multa variável entre $R \$ 5.000,00$ e $R \$ 25.000,00$ ou o equivalente ao custo da propaganda, se este for maior (art. 36, $\$ 3^{\circ}$ da Lei 9.504/1997) ${ }^{15}$.

Como o próprio termo designa, a propaganda intrapartidária é a propaganda interna, que não é levada ao conhecimento do eleitorado, e serve para eleger aqueles que disputarão as

\footnotetext{
${ }^{14}$ CHAMON, Omar. Direito Eleitoral. 4 ed. Rio de Janeiro: Forense; São Paulo: Método, 2011, p.144.

${ }^{15}$ Ibidem, p.144.
} 
eleições. Por fim, tem-se a chamada propaganda partidária, prescrita no artigo 36 , $\S 2^{\circ}$ da Lei $n^{\circ}$ 9.504/97. Consoante Omar Chamon, a propaganda partidária pode ser tida como

[...] aquela de caráter gratuito, gravada ou ao vivo, efetuada mediante transmissão por rádio ou televisão e realizada entre as $19 \mathrm{~h} 30$ e às $22 \mathrm{~h}$, com o objetivo exclusivo de difundir os programas partidários, transmitir mensagens aos filiados sobre a execução do programa partidário, os eventos com este relacionados e as atividades congressuais do partido, ou, ainda, divulgar a posição do partido em relação a temas político-comunitários. ${ }^{16}$

De fato, a propaganda partidária é aquela cuja finalidade é a divulgação dos programas dos partidos políticos, transmitir mensagens aos filiados e eleitores, bem como divulgar atividades dos partidos em geral. Ressalte-se, outrossim, a disciplina legal da referida propaganda, in verbis: “Art. 36.omissis [...] omissis § $2^{\circ}$ No segundo semestre do ano da eleição, não será veiculada a propaganda partidária gratuita prevista em lei nem permitido qualquer tipo de propaganda eleitoral paga no rádio e na televisão." Destaque-se que a propaganda partidária é uma forma de manifestação do chamado 'direito de antena', previsto no art. $17, \$ 3^{\circ}$ da CF e restrito aos partidos políticos.

\title{
3. INTERNET E PROPAGANDA ELEITORAL
}

O Direito eleitoral é diuturnamente provocado, no seu arcabouço positivo, a adaptar-se às mudanças provocadas pelo avanço tecnológico e disseminação em escala mundial da Internet. Sobre o alcance das mudanças advindas das mutações no aparato tecnológico, Barreto Junior estabelece que:

\begin{abstract}
A sociedade contemporânea atravessa uma verdadeira revolução digital em que são dissolvidas as fronteiras entre telecomunicações, meios de comunicação de massa e informática. Convencionou-se nomear esse novo ciclo histórico de Sociedade da Informação, cuja principal marca é o surgimento de complexas redes profissionais e tecnológicas voltadas à produção e ao uso da informação, que alcançam ainda sua distribuição através do mercado, bem como as formas de utilização desse bem para gerar conhecimento e riqueza. ${ }^{17}$
\end{abstract}

\footnotetext{
${ }^{16}$ Ibidem, p.143.

17 BARRETO JUNIOR, Irineu Francisco. Atualidade do Conceito Sociedade da Informação para a Pesquisa Jurídica. In: PAESANI, Liliana Minardi (coord.). Direito na Sociedade da Informação. São Paulo: Atlas, 2007, p.62.

REDESG / Revista Direitos Emergentes na Sociedade Global - www.ufsm.br/redesg v. 1, n. 2, jul.dez/2012

Revista do Programa de Pós-graduaÇão em Direito da Universidade FEderal de SANTA Maria - www.ufsm.br/ppgd
} 
A propaganda eleitoral, uma das faces das campanhas políticas submetidas à mutações advindas da Internet e das novas tecnologias, encontra-se regulada, em linhas gerais, no Código Eleitoral e na Lei n. ${ }^{\circ}$ 9.504/97 - Lei das Eleições, os quais, originalmente, não dispuseram sobre a propaganda eleitoral na rede mundial de computadores, tendo em vista que, quando foram editados, a rede mundial de computadores não existia ou tinha uma utilização muito restrita. Sem embargo, deve-se salientar que os princípios que regem a propaganda em geral, e os limites que thes são impostos pela legislação eleitoral e pelas resoluções do TSE, devem ser aplicados, naquilo que for cabível, à propaganda em meio virtual18.

Em virtude da inexistência de lei específica sobre esse tipo de propaganda eleitoral, a partir das eleições de 2000, o TSE, no uso do seu poder normativo, dispôs por intermédio da Resolução n. ${ }^{\circ}$ 20.684, que os candidatos poderiam fazer uso do domínio www.nomedocandidatonumerodocandidato.can.br, para divulgação de propaganda na Internet, contudo, não trouxe outras disposições mais específicas.

Em 2002, o TSE expediu a Resolução n. ${ }^{\circ} 20.988$, que estabeleceu que a propaganda na internet estivesse sujeita às mesmas restrições impostas à programação normal do rádio e da televisão, inclusive quanto aos debates, além de manter a propaganda por meio do domínio www.nomedocandidatonúmerodocandidatouf.can.br e vedar a realização de qualquer tipo de propaganda em página de provedores de acesso à internet, em qualquer período.

Nas eleições que se seguiram tais disposições foram praticamente repetidas. Nas eleições municipais de 2008, diversas consultas foram formuladas ao TSE, no entanto, aquela Corte decidiu não conhecê-las, sob o argumento de que questionamentos múltiplos elaborados de maneira esmiuçada e ampla ou que incidam em caso concreto não mereciam conhecimento, deixando que os casos concretos fossem resolvidos individualmente nos respectivos processos 19

Em 2009, o Congresso Nacional editou a Lei n. ${ }^{\circ} 12.034$, de 29 de setembro de 2009, que alterou as Leis $n .^{\circ} 9.504 / 97$ e n. ${ }^{\circ} 9.096 / 95$, trazendo algumas disposições sobre a propaganda eleitoral na internet, cujo detalhamento será feito a seguir.

\footnotetext{
${ }^{18}$ VELLOSO, Carlos Mário da Silva. AGRA, Walber de Moura. Elementos de Direito Eleitoral. São Paulo: Saraiva.2009, p. 149.

${ }_{19}$ Consulta n. ${ }^{\circ}$ 1477: Consulta. Propaganda eleitoral, via internet ou por outros meios eletrônicos de comunicação. Multiplicidade de questões. Solução caso a caso. Consulta não conhecida. Questionamentos múltiplos elaborados de maneira esmiuçada e ampla ou que incidam em caso concreto não merecem conhecimento. BRASIL. TSE. Resolução n. ${ }^{\circ}$ 22.832. Relator Min. Ari Pargendler. Diário de Justiça, 06/ago/2008, p. 32.

REDESG / Revista Direitos Emergentes na Sociedade Global - www.ufsm.br/redesg v. 1, n. 2, jul.dez/2012 ReVIsta do Programa de Pós-graduaÇão em DiReito da UniverSidAde Federal de SANTA MARIA - www.ufsm.br/ppgd
} 


\subsection{Lei $\mathrm{N}^{\circ} 12.034 / 2009$}

A lei $n^{\circ} 12.034$ de 2009, que incluiu os artigos 57-A até o artigo 57-I, na Lei $n^{\circ}$ 9.504/97, traz no seu corpo, a possibilidade da utilização da rede mundial de computadores como meio de divulgação e propaganda de campanhas eleitorais.

0 texto do art. 57-A é taxativo quando determina sua utilização, vejamos: “Art. 57-A. é permitida a propaganda eleitoral na internet, nos termos desta Lei, após o dia 5 de julho do ano da eleição." Dessa forma, o legislador introduziu no contexto eleitoral mais essa ferramenta de mídia, muito embora, na eleição de 2006 e 2008, os candidatos já fizeram uso dessa ferramenta. Todavia, o legislador não esgotou assim a normatização sobre o assunto, detalhando ainda de forma incipiente as relações jurídicas do certame.

Já o artigo 57-B, traz consigo as formas que o candidato poderá lançar mão para realizar a campanha via internet, a saber:

Art. 57-B. a propaganda eleitoral na internet poderá ser realizada nas seguintes formas:

Em sítio do candidato, com endereço eletrônico comunicado à Justiça Eleitoral, e hospedado, direta ou indiretamente, em provedor de serviço de internet estabelecido no País;

Em sítio do partido ao da coligação, com endereço eletrônico comunicado a Justiça Eleitoral e hospedado, direta ou indiretamente, em provedor de serviço de internet estabelecido no País;

Por meio de mensagem eletrônica para endereços cadastrados gratuitamente pelo candidato, partido ou coligação;

Por meio de blogs, redes sociais, sítios de mensagens instantâneas, e assemelhados, cujo conteúdo seja gerado ou editado por candidatos, partidos ou coligações ou de iniciativa de qualquer pessoa natural;

Pelo exposto, o candidato, partido ou coligação poderão utilizar de sítio destinado à propaganda eleitoral, uma vez que os mesmos registrem o endereço eletrônico na Justiça Eleitoral no momento do pedido do registro da candidatura. Destarte, essas ferramentas, possibilitam que o candidato, partido ou coligação enviem mensagens eletrônicas para endereços cadastradas gratuitamente, sendo expressamente vedada a utilização das famigeradas malas diretas, adquiridas por meio de empresas especializadas em banco de dados.

Vale ressaltar que, a vedação ao uso das malas diretas é um tanto quanto inatingível, uma vez que a fiscalização desse expediente é indubitavelmente impraticável. Isto posto, tais expedientes podem ser descritos por meio de blogs, redes sociais (Orkut, Facebook, twiter, etc.) sites de mensagens instantâneas (SMS, MSN, etc), cujo conteúdo seja gerado por um dos agentes políticos destacados nos artigos, ou de iniciativa de qualquer eleitor, podendo ser executados 
por profissionais habilitados (jornalistas, etc). Avançado no tema, destacamos o intuito do legislador em diminuir os custos de campanha, proporcionando aos candidatos uma igualdade de condições, ao menos na internet. Senão vejamos:

Art. 57-C. Na internet é vedada a veiculação de qualquer tipo de propaganda paga.

$\$ 1^{\circ}$ É vedada, ainda que gratuitamente, a veiculação de propaganda eleitoral na Internet, em sítios:

I-De pessoas jurídicas, com ou sem fins lucrativos;

II-Oficiais ou hospedados por órgãos ou entidades da administração pública direta ou indireta da União, dos Estados, do Distrito Federal e dos Municípios.

$\$ 2^{\circ}$ A violação do disposto neste artigo sujeita o responsável pela divulgação da propaganda e, quando comprovado seu prévio conhecimento, o beneficiário à

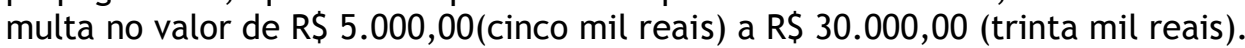

Nesse diapasão, é vedado qualquer tipo de veiculação a título oneroso nos sítios da internet. Ainda, mesmo que gratuitamente, está vedada a publicação de propaganda eleitoral em sítios de pessoas jurídicas, com ou sem fins lucrativos, e em sítios oficiais ou hospedados por órgão ou entidades da administração pública direta ou indireta da União dos Estados e dos Municípios. O descumprimento desse artigo acarretara ao responsável pela divulgação da propaganda e o beneficiário, quando comprovado seu consentimento, ao pagamento de multa no valor de $\mathrm{R} \$ 5.000,00$ a $\mathrm{R} \$ 10.000,00$.

Art. 57-D. É livre a manifestação do pensamento, vedado o anonimato durante a campanha eleitoral, por meio da rede mundial de computadores - internet, assegurado o direito de resposta, nos termos das alíneas a, b e c do inciso IV do $\S$ 30 do art. 58 e do 58-A, e por outros meios de comunicação interpessoal mediante mensagem eletrônica.

$\S 1$ (VETADO)

§ 2 A violação do disposto neste artigo sujeitará o responsável pela divulgação da propaganda e, quando comprovado seu prévio conhecimento, o beneficiário à multa no valor de $\mathrm{R} \$ 5.000,00$ (cinco mil reais) a $\mathrm{R} \$ 30.000,00$ (trinta mil reais).

Não é permitido o anonimato na utilização das ferramentas de internet na propaganda eleitoral. É livre a manifestação do pensamento, assegurado o direito de resposta, nos termos das alíneas a, b,e c do inciso IV do $\$ 3^{\circ}$ do art. 58 e 58-A, e por outros meios de comunicação interpessoal mediante mensagem eletrônica. Portanto, o direito de resposta poderá ser exercido por meio diverso daquele utilizado pelo ofensor.

Art. 57-E. São vedadas às pessoas relacionadas no art. 24 a utilização, doação ou cessão de cadastro eletrônico de seus clientes, em favor de candidatos, partidos ou coligações.

§ 1 É proibida a venda de cadastro de endereços eletrônicos. 
§ 2 A violação do disposto neste artigo sujeita o responsável pela divulgação da propaganda e, quando comprovado seu prévio conhecimento, o beneficiário à multa no valor de $\mathrm{R} \$ 5.000,00$ (cinco mil reais) a $\mathrm{R} \$ 30.000,00$ (trinta mil reais).

Os órgão, pessoas e entidades relacionadas no caput do artigo 24 são proibidos de utilizarem, doarem ou cederem seus cadastros eletrônicos de clientes em favor de candidatos, partido ou coligações sob pena de multa, inclusive para o beneficiário, quando comprovado seu envolvimento. É proibido a venda de cadastros de endereços eletrônicos, sob pena da multa da lei, contido, de difícil comprovação.

\begin{abstract}
Art. 57-F. Aplicam-se ao provedor de conteúdo e de serviços multimídia que hospeda a divulgação da propaganda eleitoral de candidato, de partido ou de coligação as penalidades previstas nesta Lei, se, no prazo determinado pela Justiça Eleitoral, contado a partir da notificação de decisão sobre a existência de propaganda irregular, não tomar providências para a cessação dessa divulgação.

Parágrafo único. 0 provedor de conteúdo ou de serviços multimídia só será considerado responsável pela divulgação da propaganda se a publicação do material for comprovadamente de seu prévio conhecimento.
\end{abstract}

Este dispositivo determina ao provedor de conteúdo e de serviços que hospeda a divulgação ilegal da propaganda eleitoral de candidatos, partido ou coligação, as penalidades previstas nos artigos anteriores. Mas neste caso, as penalidades somente serão aplicadas ao provedor se, no prazo determinado pela Justiça Eleitoral, contado a partir da notificação da decisão sobre a existência de propaganda irregular, diretamente encaminhada e entregue pelo interessado ao provedor de internet, na qual deverá constar de forma clara e detalhada a propaganda por ele considerada irregular, este não adotar as providências necessárias para fazer cessar a divulgação ilegal.

Art. 57-G. As mensagens eletrônicas enviadas por candidato, partido ou coligação, por qualquer meio, deverão dispor de mecanismo que permita seu descadastramento pelo destinatário, obrigado o remetente a providenciá-lo no prazo de quarenta e oito horas.

Parágrafo único. Mensagens eletrônicas enviadas após o término do prazo previsto no caput sujeitam os responsáveis ao pagamento de multa no valor de $\mathrm{R} \$ 100,00$ (cem reais), por mensagem.

O artigo determina, ainda, que as mensagens eletrônicas enviadas os candidato, partido ou coligação, qualquer que seja o meio, devem dispor de mecanismos que permita o descadastramento do destinatário, caso este deseje fazê-lo, ficando, neste caso, o remetente obrigado a fazê-lo no prazo de 48 horas. Encerrado o prazo, solicitado sem que este tenha sido 
feito, ficam os responsáveis sujeitos ao pagamento de multa, por mensagem no valor de R\$ 100,00 . Isso porque a vontade do eleitor tem de ser respeitada.

Art. 57-H. Sem prejuízo das demais sanções legais cabíveis, será punido, com multa de R\$ 5.000,00 (cinco mil reais) a R\$ 30.000,00 (trinta mil reais), quem realizar propaganda eleitoral na internet, atribuindo indevidamente sua autoria a terceiro, inclusive a candidato, partido ou coligação.

Aquele que indevidamente utilizar nome de terceiro para enviar mensagens eletrônicas estará sujeito às penalidades do artigo acima.

Art. 57-I. A requerimento de candidato, partido ou coligação, observado o rito previsto no art. 96, a Justiça Eleitoral poderá determinar a suspensão, por vinte e quatro horas, do acesso a todo conteúdo informativo dos sítios da internet que deixarem de cumprir as disposições desta Lei.

§ 1 A cada reiteração de conduta, será duplicado o período de suspensão.

§ 2 No período de suspensão a que se refere este artigo, a empresa informará, a todos os usuários que tentarem acessar seus serviços, que se encontra temporariamente inoperante por desobediência à legislação eleitoral.

O candidato, partido político ou coligação tem legitimidade ativa para requerer a suspensão, por vinte e quatro horas, do acesso a todo conteúdo informativo dos sítios da internet que descumprirem as disposições contidas nesta lei. Caso haja reincidência de conduta, a cada reiteração será duplicado o período de suspensão do provedor, e durante este período de suspensão, a empresa fica obrigada a informar a todos os usuários que tentarem acessar os seus serviços que se encontra temporariamente inoperante por desobediência da legislação eleitoral.

Finalmente, com o advento da legislação ora estudada, e que teve efeito com o grande sucesso da campanha para Presidente do Estado Unidos da América, Barack Obama, que, por meio da internet causou grande impacto nesse novo tipo de propaganda e divulgação de campanhas eleitorais. De acordo com relato de Graef, "a eleição de Obama à Presidência dos EUA em 2008 representa a Apolo II, a missão que colocou um homem na lua pela primeira vez." 20

Ademais, a campanha do norte americano arrecadou aproximadamente US\$ 500 milhões (meio bilhão de dólares) em doações, motivo pelo qual nossa legislação já prevê esse tipo de concessão via internet, o que antes era impensado. Sem contar a grande repercussão das redes sociais, tal como o Facebook, Twitter, blogs pessoais, etc. ${ }^{21}$

As campanhas eleitorais estadunidenses, na Internet, avançaram para além das meras possibilidades de arrecadação e mobilização, ao uso da plataforma web como fator de prestação

\footnotetext{
${ }^{20}$ GRAEFF, Antonio. Eleição 2.0. A Internet e as Mídias Sociais no Processo Eleitoral. São Paulo: Publifolha, 2009, p.14.

${ }^{21}$ Ibid, p.15-19. 
de contas, divulgação e transparência nas disputas políticas. Nos termos da Federal Election Campaign Laws, § 438a.2, in verbis:

$\S 438 a .2$ Maintenance of website of election reports

(a) In general. The Federal Election Commission shall maintain a central site on the Internet to make accessible to the public all publicly available electionrelated reports and information.

(b) Election-related report. In this section, the term 'election-related report' means any report, designation, or statement required to be filed under the Federal Election Campaign Act of 1971.

(c) Coordination with other agencies. Any Federal executive agency receiving election-related information which that agency is required by law to publicly disclose shall cooperate and coordinate with the Federal Election Commission to make such report available through, or for posting on, the site of the Federal Election Commission in a timely manner. ${ }^{22}$

Dessa forma, encerrados os títulos legais que asseguram a utilização da internet para divulgação de propaganda eleitoral, vejamos a corroboração do Tribunal Superior Eleitoral, na resolução n 23.191/09, que dispõe sobre esse certame.

\subsection{Resolução $n^{\circ} 23.191 / 09$ do TSE}

A propaganda eleitoral consiste em toda ação destinada ao convencimento do eleitor, objetivando conquistar o seu voto. De um lado, apresenta-se como direito dos partidos e candidatos, mas por outro, constitui também direito do eleitor conhecer a vida pregressa e as propostas daqueles que pretendem exercer os cargos eletivos. Até as eleições de 2008, a legislação brasileira pouco dispunha sobre a propaganda eleitoral na internet, mesmo porque a Constituição Federal assegura como direitos fundamentais a liberdade de informação e de expressão do pensamento. Contudo, a Lei n. ${ }^{\circ} 12.034$, de 29 de setembro de 2009, trouxe várias disposições sobre essa modalidade de propaganda eleitoral, as quais serão objeto de análise. Portanto, cumpre esclarecer que a definição de propaganda eleitoral na visão do TSE, Ac $n^{\circ}$ 16.183, de 17 de fevereiro de 2000 , é a seguinte:

Entende-se como ato de propaganda eleitoral aquele que leva ao conhecimento geral, ainda que de forma dissimulada, a candidatura, mesmo que apenas postulada, a ação política que se pretende desenvolver ou razoes que induzam a concluir que o beneficiário é mais apto ao exercício de função publica. Sem tais características poderá haver mera promoção pessoal - apta, em determinadas circunstâncias a configurar abuso de poder econômico - mas não propaganda eleitoral. Com base no conceito de propaganda eleitoral.

\footnotetext{
${ }^{22}$ USA. THE FEDERAL ELECTION COMMISSION. Federal Election Campaign Laws. Disponível em: < http://www.fec.gov/law/feca/feca.pdf>. Acesso em 03. Dez. 2012. 
Assim, estabelecido o conceito de propaganda eleitoral, o TSE publicou a resolução ora em estudo, para estabelecer critérios para as eleições gerais de 2010. Dessa forma, o capítulo IV da Resolução $n^{\circ}$ 23.191/09 do TSE, guardou sua orientações quanto da propaganda eleitoral na internet, senão vejamos: 0 artigo 19 abre o capítulo com a data na qual será permitido o início da campanha pela internet, após o dia 5 de julho. Em obediência ao calendário eleitoral, poderão os candidatos, partidos políticos e coligações utilizarem a ferramenta da internet para propaganda eleitoral: “Art. 19. É permitida a propaganda eleitoral na internet após o dia 5 de julho do ano da eleição (Lei nº 9.504/97, art. 57-A)." Já o art. 20, traz as forma de utilização dessa ferramenta, como visto na lei.

Art. 20. A propaganda eleitoral na internet poderá ser realizada nas seguintes formas (Lei $\mathrm{n}^{\circ}$ 9.504/97, art. 57-B, incisos I a IV):

I - em sítio do candidato, com endereço eletrônico comunicado à Justiça Eleitoral e hospedado, direta ou indiretamente, em provedor de serviço de internet estabelecido no País;

II - em sítio do partido ou da coligação, com endereço eletrônico comunicado à Justiça Eleitoral e hospedado, direta ou indiretamente, em provedor de serviço de internet estabelecido no País;

III - por meio de mensagem eletrônica para endereços cadastrados gratuitamente pelo candidato, partido ou coligação;

IV - por meio de blogs, redes sociais, sítios de mensagens instantâneas e assemelhados, cujo conteúdo seja gerado ou editado por candidatos, partidos ou coligações ou de iniciativa de qualquer pessoa natural.

A preocupação se intensifica no quesito propaganda eleitoral via internet paga, dessa forma, a resolução reafirma esses conceitos.

\footnotetext{
Art. 21. Na internet, é vedada a veiculação de qualquer tipo de propaganda eleitoral paga (Lei $n^{\circ}$ 9.504/97, art. 57-C, caput).

$\S 1^{\circ}$ É vedada, ainda que gratuitamente, a veiculação de propaganda eleitoral na internet, em sítios (Lei no 9.504/97, art. 57-C, § $1^{\circ}$, I e II):

I - de pessoas jurídicas, com ou sem fins lucrativos;

II - oficiais ou hospedados por órgãos ou entidades da administração pública direta ou indireta da União, dos estados, do Distrito Federal e dos municípios.

$\S 2^{\circ} \mathrm{A}$ violação do disposto neste artigo sujeita o responsável pela divulgação da propaganda e, quando comprovado seu prévio conhecimento, o beneficiário à multa no valor de $\mathrm{R} \$ 5.000,00$ (cinco mil reais) a $\mathrm{R} \$ 30.000,00$ (trinta mil reais) (Lei $n^{\circ}$ 9.504/97, art. 57-C, § $2^{\circ}$ ).
}

Evidencia ainda mais sua abrangência, na observância da proibição do anonimato, como podemos observar no art. 22. 
Art. 22. É livre a manifestação do pensamento, vedado o anonimato durante a campanha eleitoral, por meio da rede mundial de computadores - internet, assegurado o direito de resposta, nos termos das alíneas a, b e c do inciso IV do $\S$ 30 do art. 58 e do art. 58-A da Lei $\mathrm{n}^{\circ}$ 9.504/97, e por outros meios de comunicação interpessoal mediante mensagem eletrônica (Lei $n^{\circ}$ 9.504/97, art. 57-D, caput).

Parágrafo único. A violação do disposto neste artigo sujeitará o responsável pela divulgação da propaganda e, quando comprovado seu prévio conhecimento, o beneficiário à multa no valor de $\mathrm{R} \$ 5.000,00$ (cinco mil reais) a $\mathrm{R} \$ 30.000,00$ (trinta mil reais) (Lei $\mathrm{n}^{\circ}$ 9.504/97, art. 57-D, § $2^{\circ}$ ).

Observa ainda a questão das doações, suas proibições e as penalidades para o descumprimento.

Art. 23. São vedadas às pessoas relacionadas no art. 24 da Lei $n^{\circ} 9.504 / 97$ a utilização, doação ou cessão de cadastro eletrônico de seus clientes, em favor de candidatos, partidos ou coligações (Lei $n^{\circ}$ 9.504/97, art. 57-E, caput).

$\S 10$ É proibida a venda de cadastro de endereços eletrônicos (Lei $n^{\circ}$ 9.504/97, art. $57-\mathrm{E}, \S 1^{\circ}$ ).

§ 20 A violação do disposto neste artigo sujeita o responsável pela divulgação da propaganda e, quando comprovado seu prévio conhecimento, o beneficiário à multa no valor de $\mathrm{R} \$ 5.000,00$ (cinco mil reais) a $\mathrm{R} \$ 30.000,00$ (trinta mil reais) (Lei $\mathrm{n}^{\circ}$ 9.504/97, art. 57-E, § $2^{\circ}$ ).

Reverbera as posições quanto às responsabilidades e penalidades dos provedores de internet.

Art. 24. Aplicam-se ao provedor de conteúdo e de serviços multimídia que hospeda a divulgação da propaganda eleitoral de candidato, de partido ou de coligação as penalidades previstas nesta resolução, se, no prazo determinado pela Justiça Eleitoral, contado a partir da notificação de decisão sobre a existência de propaganda irregular, não tomar providências para a cessação dessa divulgação (Lei n 9.504/97, art. 57-F, caput).

$\S 1^{\circ} \mathrm{O}$ provedor de conteúdo ou de serviços multimídia só será considerado responsável pela divulgação da propaganda se a publicação do material for comprovadamente de seu prévio conhecimento (Lei $n^{\circ}$ 9.504/97, art. 57-F, parágrafo único).

$\S 2^{\circ} \mathrm{O}$ prévio conhecimento de que trata o parágrafo anterior poderá, sem prejuízo dos demais meios de prova, ser demonstrado por meio de cópia de notificação, diretamente encaminhada e entregue pelo interessado ao provedor de internet, na qual deverá constar de forma clara e detalhada a propaganda por ele considerada irregular.

Complementa com os famosos spams eleitorais.

Art. 25. As mensagens eletrônicas enviadas por candidato, partido ou coligação, por qualquer meio, deverão dispor de mecanismo que permita seu descadastramento pelo destinatário, obrigado o remetente a providenciá-lo no prazo de 48 horas (Lei n 9.504/97, art. 57-G, caput). 
Parágrafo único. Mensagens eletrônicas enviadas após o término do prazo previsto no caput sujeitam os responsáveis ao pagamento de multa no valor de $\mathrm{R} \$ 100,00$ (cem reais), por mensagem (Lei $\mathrm{n}^{\circ}$ 9.504/97, art. 57-G, parágrafo único). E por fim, penaliza a utilização da internet com nome de terceiros.

Art. 26. Sem prejuízo das demais sanções legais cabíveis, será punido, com multa de $\mathrm{R} \$ 5.000,00$ (cinco mil reais) a $\mathrm{R} \$ \mathbf{3 0 . 0 0 0 , 0 0}$ (trinta mil reais), quem realizar propaganda eleitoral na internet, atribuindo indevidamente sua autoria a terceiro, inclusive a candidato, partido ou coligação (Lei n 9.504/97, art. 57-H).

Dessa forma, observa-se o esforço normativo de adaptar a legislação brasileira às mudanças sociais e política advindas da Sociedade da Informação que, por atingir a diferentes aspectos da sociabilidade humana, atingem também a dimensão política dos sufrágios eleitorais.

\section{CONCLUSÃO}

A Internet, como veículo de informação responsável por um marco mundial no tocante à integração de comunicação e ainda, responsável por uma nova realidade, denominada Sociedade da Informação, integrou-se ao sistema eleitoral como em todos os campos de incidência da sociedade. As mais diversas relações jurídicas e sociais podem ser mantidas por meio da Internet. A utilização da tecnologia, em se tratando de Direito Eleitoral não é uma novidade, se considerarmos, por exemplo, o voto eletrônico.

Assim, inicialmente, a ausência de regulamentação tornou-se um problema. Atendendo às transformações sociais, foi editada a lei, e com ela regramentos específicos para permitir a propaganda eleitoral por meio da Internet. A regulamentação da propaganda eleitoral por meio da Internet, assim como a propaganda por meio televisivo, radiodifusão ou impresso, respeita rígidos critérios no tocante à sua veiculação. Existe período predeterminado no calendário eleitoral para que possam veicular informações de cunho eleitoral propagandístico.

Destarte, com base em todos os elementos trazidos no corpo do presente artigo, fica claro que nossa legislação é muito incipiente, devendo a jurisprudência cuidar de apresentar soluções mais condizentes com nosso princípios gerais e eleitorais, assim, poderemos imaginar um universo democrático, e de baixo custo, a fim de favorecer disputas eleitorais mais justas. Ademais fica evidente que falta ao TSE meios mais fortes de controle das informações apresentadas por meio da internet, bem como possibilitar que sejam acessados os provedores de internet, implicando necessariamente num processo mais transparente. 


\section{REFERÊNCIAS}

AMAURY, Silva. Reforma Eleitoral. Leme/SP: J.H.Mizuno, 2010.

BARRETO JUNIOR, Irineu Francisco. Atualidade do Conceito Sociedade da Informação para a pesquisa jurídica. In: PAESANI, Liliana Minardi (coord.). O Direito na Sociedade da Informação. São Paulo: Atlas, 2007.

Abordagens recentes da pesquisa jurídica na Sociedade da Informação. In: GRAEFF, Antonio. Eleição 2.0. A Internet e as Mídias Sociais no Processo Eleitoral. São Paulo: Publifolha, 2009, p.14.

PAESANI, Liliana Minardi (coord.). O Direito na Sociedade da Informação II. São Paulo: Atlas, 2009

CANOTILHO, J.J. Gomes. Direito constitucional e teoria da Constituição. $2^{\mathrm{a}}$ ed. Coimbra: Almedina, 1998.

CERQUEIRA, Thales Tácito Pontes. Direito Eleitoral Brasileiro: doutrina, jurisprudência e legislação. Belo Horizonte, MG:Del Rey, 2002.

CÂNDIDO, Joel J. Direito Eleitoral Brasileiro. 13 ed. Bauru, SP:Edipro, 2008.

CHAMON, Omar. Direito Eleitoral. 4 ed. Rio de Janeiro:Forense, 2011.

COÊLHO, Marcos Vinicius Furtado. Direito Eleitoral e Processo Eleitoral-Direito penal eleitoral e direito político. $2^{\mathrm{a}}$ ed., Rio de Janeiro: Renovar, 2010.

FERREIRA FILHO, Manoel Gonçalves. Curso de Direito Constitucional. 35 ed. São Paulo: Saraiva, 2009.

JARDIM, Torquato. Direito Eleitoral Positivo. Brasília, DF: Livraria e Editora Brasília Jurídica, 1996.

MORAES, Alexandre de. Direito Constitucional. 25 ed. São Paulo:Atlas, 2010.

Malheiros Editores, 1998.

RIBEIRO, Fávila. Direito Eleitoral. 5 ed. Rio de Janeiro:Forense, 1998.

SILVA, José Afonso da. Curso de Direito Constitucional Positivo. 33 ed. São Paulo: Malheiros Editores, 2009.

USA. THE FEDERAL ELECTION COMMISSION. Federal Election Campaign Laws. Disponível em: < http: //www.fec.gov/law/feca/feca.pdf>. Acesso em 03. Dez. 2012.

VELLOSO, Carlos Mário da Silva. AGRA, Walber de Moura. Elementos de Direito Eleitoral. São Paulo: Saraiva, 2009.

Recebido em: 15.10 .2012

Revisado em: 11.01.2013

Aprovado em: 31.01 .2013

REDESG / Revista Direitos Emergentes na Sociedade Global - www.ufsm.br/redesg v. 1, n. 2, jul.dez/2012

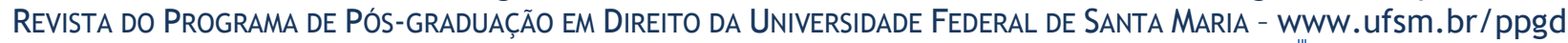

